\title{
The Relationship between Mobile Phone Usage in Classroom and Academic Achievement in College Life
}

\author{
https://doi.org/10.3991/ijim.v12i8.9530 \\ Ariana Yunita ${ }^{\square}$, Nursechafia, Erwin Setiawan, Herminarto Nugroho \\ Universitas Pertamina, Jakarta, Indonesia \\ ariana.yunita@universitaspertamina.ac.id \\ Hani Ramadhan \\ Pusan National University, Busan, South Korea
}

\begin{abstract}
The use of mobile phone has been increasing nowadays in most part of the world and it has become the phenomenon where people cannot live without. This study aims to reveal whether mobile phone use affects student's academic achievement compared to other factors such as study program, student's focus and gender. The frequent of mobile phone use and how excellence student's academic performance will be analysed. A survey has been conducted to large number of college students. A questionnaire was developed and delivered by online questionnaire to 513 students of Universitas Pertamina, Jakarta, Indonesia. Using Ordinary Least Square's result statistical analysis, it can be concluded that gender and study program have significant effects to GPA, while the use of mobile phone and its effect of distracting student's focus are not significant to GPA. Furthermore, female students significantly scored higher GPA result by 0.23 point than male students, cateris paribus. Then, students from social sciences have higher GPA results by 0.2 point than students from engineering sciences, cateris paribus. Generally, the results should be interesting for decision maker in academic field on how important to embrace mobile phone for learning style.
\end{abstract}

Keywords—academic achievement, education, mobile phone, university

\section{$1 \quad$ Introduction}

The continuous and rapid development of technology has transformed lifestyle of society. Digital era makes people tend to be online everyday and leads to the world without border. Several facilities and services are offered to meet person's needs by using mobile phone such as food delivery, shuttle service, expert consultation as well as finance management. It leads to an increase of mobile phone users everydays. According to world-statistics.org, within one decade, from 2008 until 2018, mobile cellular subscriptions are roughly increased 5 times. For some cases, this phenomenon might affect educational world.

The impact of digital transformation changes the way of education both inside and outside the classroom. The use of learning media and devices such as e-learning and 
MOOC (Massive Open Online Course) have been integrated in smart phone and utilized by learners (Yuan, Powell, 2013). Another research shows that the use of information technology in middle school may help students to increase their academic performances (Lei and Zhao, 2007). However, the use of smart phone also has negative issues and might lead to several conditions such as internet addiction disorder (Starcevic, 2013; Wallace, 2014), accidents for pedestrians (Nasar \& Werner, 2013) as well as health and lifestyle (Wallace, 2014).

Internet addiction might change person's lifestyles. One of them is the tendency to be less communicative and avoid public speaking, hence, they prefer texting to talking (Muduli, 2014). Moreover, the worse impact of problematic internet use is persons can suffer internet addicition disorder that leads to impairment or distress (Weinstein et al, 2014). On the other hand, the usage of social media is good and collaborative. It is assumed to improve the quality of education for college students (Irwin et al. 2012; Kirschner \& Karpinski 2010; Junco, Elavsky \& Heiberger 2013). Another existing technology, instant messaging, proved to grab student's attention from academic activities and brings negative impact for students' lifestyle (Yeboah and Ewur 2014).

From those studies above, the relationship between technology addiction and academic achievement of higher education students have not been directly explored. Therefore, further study is needed to understand the impact of smart phone use to their academic performances. Based on data collected from students in a university, the purpose of this research is to investigate the following questions: 1) Are GPAs of students in Universitas Pertamina affected by smart phone use? 2) Is there any relationship between mobile phone use, GPA and student's focus in Universitas Pertamina?

\section{$2 \quad$ Literature Review}

\subsection{Factors Influencing GPA}

Grade Point Average (GPA) is widely used to measure how learners achieve the learning outcomes. GPA is generally claimed as a benchmark of students' academic performance which determines students are being dropped out or not. Therefore, an increase of GPA each semester for students is very essential. According to several studies, there are several factors influencing academic performances, which are both internal and external factors. Internal factors include self-efficacy (Robbins et al. 2004), clear academic goals and motivation (Al Shawwa et al, 2015). While external factors might be transition issues from high school to college (Stewart \& Kim, 2015) and inappropriate use of social networking (Al Shawwa et al, 2015). In addition, demographic factors such as gender, race/ethnicity, income to be significant for academic performances of students aged more than 25 in undergraduate studies (Markle, 2015).

\subsection{Information and Communication Technology for Learning}

Currently, learning styles have adapted to the rapid growth of information technology development. The adoption of information and communication technology in 
learning style aims to increase the collaboration between a teacher and students at class and to enhance learning experiences (Kirkup and Kirkwood 2005; Buttar 2016).

According to several research, below are common tools, softwares or applications used in learning activities.

1. Smart Phone. Smart device technology, that allows learners to complete various problems, triggers the possibility of smart phone integration in the lecture. Studies on the restructuring of lecture-based learner gives a view about the possibility of shifting the use of the device as one of the technologies which are included in the lecture concept (Biddix, Chung, and Park 2015). Smart mobile gadget (smart mobile gadgets) plays roles as complementary learning resources, lecture material storage that can be accessed easily, and user-friendly discussion platform by chatting applications like KakaoTalk.

2. E-learning. E-learning implementation for higher education, especially for blended learning (a learning method that accommodate students to study at classroom and online through e-learning), supports dropout rate reduction and exam pass rate improvement in certain subject subjects (López-Pérez et al, 2011). Despite having some limitations, shortcomings, and strength, e-learning is recommended for lecture planners to use in order to maximize collaborative and interesting learning (Kattoua et al, 2016).

3. Social media. Based on a research review on the role of social media at college (Tess, 2013), the use of social media in the lecture has emerged a possible integration of social media usage in lectures. However, the teachers have not been responsive in realizing the adoption of social media as the educational facilities, though present, is still in the experimental stage.

4. Instant messaging or online chat applications. In lectures, the use of short messages can support learning effectively and more personally for each student (Bouhnik and Deshen 2014; Amry 2014; Yeboah and Ewur 2014). In future, messaging services such as Whatsapp provide opportunities as integration option inside or outside the classroom to enhance learning experience.

\subsection{Technology Use Factor on Academic Performance}

Current digital technology application for education is very well known for both inside and outside the classroom. A lot of assignments have integrated hardware and software for completion, such as paper writing, data processing, data sources, and video creation. Application of Information Technology and Communication (ICT) to support learning process has been applied even from the level elementary school (Warsihna, 2015). On one hand, the application of ICTs is useful in the classroom to support learning. On the other hand, the study analyzes the effects of technology use by learners in middle schools in Ohio, USA, (Lei and Zhao 2007), proves that the use of ICT in the middle school environment have a mixed relationship with the outcome of academic performance. The integration of information technology in the classroom support learning effectively. However, its use outside the classroom is not very helpful for the learners in middle school. 
According to Lei (2007), in his research, the use of computers by learners can improve the learning outcomes with sufficient time span. However, if too much, the use of such computers can be detrimental and not significantly improve academic performance (Jacobson and Forste, 2011). On the other hand, there is still less visible correlation between the quantity of computer use and academic improvement. Generally, the use of technology still has a positive impact on related subjects with the application of such technology.

\section{$3 \quad$ Methodology}

\subsection{Data Collection}

Participants of this research were first year and second year students from Universitas Pertamina in Jakarta, Indonesia.Total number of participants are 513 students with roughly equal proportion of men and women: 262 male participants $(51.1 \%)$ and 251 female participants (48.9\%). Most of participants come from Jakarta $(25.1 \%)$ followed by West Java (18.5\%), Central Java (12.3\%), Banten (9.4\%) and East Java (8.2\%). Others are distributed from all over provinces in Indonesia, such as Aceh, Bali, Bengkulu, West Kalimantan, North Sumatera, South Sulawesi.

Data were collected over one semester within even semester 2017/2018 using online questionnaire. There are several questions that were asked to students, such as name, student's id number, department, gender, place of origin, most common applications that has been accessed using mobile phone, has the participant used mobile phone for study, the frequence of checking their mobile phone at classroom, and whether their mobile phone distract their focus or not while attending lectures.

\subsection{Model and Method}

In our model, the dependent variable is measured by GPA based on scale from 0 to 4. Valid responses are being checked using name and student's identification number from questionnaire with the legacy data from Academic Services Directorate, Universitas Pertamina.

The explanatory variables capture some of suggested theory that affect the students' academic performance (GPA). Three independent variables were constructed-gender, frequency of accessing mobile phone at class, and study program. First, gender is coded as 0 (male) and 1 (female). Second, frequency number is measured on how many times for each student check their mobile phones while in class. It only includes for the following mobile phone activities at class: never check, 1 to 2 times, and more than three times. Students who answer 'never' are removed from the dataset. Third, the variable of study program is divided into two major programs-engineering science and social sciences.

Data were analysed using Jupyter Notebook with Python and Pandas. Other statistics software, Stata and Excel, are also used for the data analysis. We estimate our model using Ordinary Least Square (OLS) regression techniques. 


\section{$4 \quad$ Findings and Discussion}

After processing the data using OLS regression, we found several interesting insights (Table 1). The variables separate into two common themes: demography (gender and study program), and mobile phone usage (frequency of checking mobile phone at classroom, the effect of mobile phone use at classroom whether distracting their focus or not). In general, those three variables that related to mobile phone usage are not significant to student's GPA. On the contrary, study programs and gender have significant impact to GPA.

Table 1. Regression Result of Students Academic Performances (GPA) on Gender, Frequency of Using Mobile Phone in Class, Focus and Study Program

\begin{tabular}{|c|c|}
\hline Variables & Coefficients \\
\hline Gender & $0.2273927 * * *$ \\
\hline \multicolumn{2}{|l|}{ Frequency } \\
\hline 1-2 times & 0.0067214 \\
\hline$\geq 3$ times & -0.0362187 \\
\hline Study Program & $0.2059726^{* * *}$ \\
\hline Focus & 0.00826 \\
\hline Constant & $0.374406 * * *$ \\
\hline
\end{tabular}

Note: ***significant at $1 \%$ alpha; ** significant at $5 \%$ alpha; *significant at $10 \%$ alpha

In term of gender, female students significantly scored higher GPA result by 0.23 point than male students, cateris paribus. Female students are more likely to seek collaboration, interaction, and assistance from fellow students, than male students. In addition, probably well-managed time management for female students than male students also affect students' academic performance. This results in line with the study of Machin and McNally (2005).

Furthermore, regarding study program, students from social sciences have higher GPA results by 0.2 point than students from engineering sciences, cateris paribus. Courses in the natural sciences and engineering are rated more difficult, are associated with harder subjects, higher study times, and have harsher grade distributions than those in the social studies. This results in line with the study of Arcidiacono et al (2012).

Arising several analysis and assumption because of the result should be confirmed in the theme of environment of learning and the usage of the smart phone itself. First, regarding the results of study program and GPA, the difficulty of social science subjects might be lower than science and engineering subjects. Second, the behaviour of mobile phone use at class should be furtherly explored. Students who check only once until twice tend to have higher GPA than students who never access their mobile phone, probably because they try to search materials related to the course that they attend. Thus, motivation for the students to open their smart phone at class should be questioned. For example, they might open several categories of non-academic applications in their phone at class, or maybe they access their mobile phone because their own initiative or based on lecturer's demand. Furthermore, students who access their mobile phone more than three times within 2 hours at classroom, their GPA seems 
lower than students who never access their mobile phone. However, other factors are not involved in this research, such whether a student has part time job or not, their parents' total income, how they travel to university and other factors that should be analysed as additional factor to improve the experience of the learning environment itself.

\section{Conclusions and Future Works}

There are two significant variables that affect students' academic performance, namely gender and study programs. Female students are more cooperative to initiate the assistance and well-manage their time than male students. Students from engineering students have harder subjects, higher study times, and have harsher grade distributions. There is a need for Academic Service Department to have various facilities to encourage male and engineering students to increase their GPAs.

It is recommended to continue to explore more interactions of students' academic performances with the factor of scholarship condition, economic conditions, and elearning facility. To ensure the success of all students, it is important to continue to study how to increase the average GPA on male students and engineering students. The role of gender identity and background of science disciplines, as well as other factors, should continue to be explored, to guarantee all students have the same opportunities for academic performance success.

\section{Acknowledgment}

We acknowledge that this research is funded by Ministry of Research and Higher Education, Indonesia.

\section{$7 \quad$ References}

[1] Al Shawwa, L., Abulaban, A.A., Abulaban, A.A., Merdad, A., Baghlaf, S., Algethami, A., Abu-Shanab, J. and Balkhoyor, A., 2015. Factors potentially influencing academic performance among medical students. Advances in Medical Education and Practice, 6, p.65.

[2] Amry, A.B., 2014. The impact of whatsapp mobile social learning on the achievement and attitudes of female students compared with face to face learning in the classroom. European Scientific Journal, ESJ, 10(22).

[3] Arcidiacono, P., Hotz, V.J. and Kang, S., 2012. Modeling college major choices using elicited measures of expectations and counterfactuals. Journal of Econometrics, 166(1), pp.316. https://doi.org/10.1016/j.jeconom.2011.06.002

[4] Biddix, J.P., Chung, C.J. and Park, H.W., 2015. The hybrid shift: Evidencing a studentdriven restructuring of the college classroom. Computers \& Education, 80, pp.162-175. https://doi.org/10.1016/i.compedu.2014.08.016

[5] Bouhnik, D. and Deshen, M., 2014. WhatsApp goes to school: Mobile instant messag-ing between teachers and students. Journal of Information Technology Education: Re-search, 13(1), pp.217-231. https://doi.org/10.28945/2051 
[6] Buttar, S.S., 2016. ICT in Higher Education. PEOPLE: International Journal of Social Sciences, 2(1).

[7] Irwin, C., Ball, L., Desbrow, B. and Leveritt, M., 2012. Students' perceptions of using Facebook as an interactive learning resource at university. Australasian Journal of Educational Technology, 28(7). https://doi.org/10.14742/ajet.798

[8] Jacobsen, W.C., and Forste, R. 2011. The Wired Generation: Academic and Social Outcomes of Electronic Media Use Among University Students. Cyberpsychology, Behavior, and Social Networking, Vo. 14(5), pp. 275-280. https://doi.org/10.1089/cyber.2010.0135

[9] Junco, R., Elavsky, C.M. and Heiberger, G., 2013. Putting twitter to the test: Assessing outcomes for student collaboration, engagement and success. British Journal of Edu-cational Technology, 44(2), pp.273-287. https://doi.org/10.1111/j.1467-8535.2012.01284.x

[10] Kattoua, T., Al-Lozi, M. and Alrowwad, A.A., 2016. A review of literature on E-learning systems in higher education. International Journal of Business Management \& Economic Research, 7(5), pp.754-762.

[11] Kirkup, G. and Kirkwood, A., 2005. Information and communications technologies (ICT) in higher education teaching - a tale of gradualism rather than revolution. Learn-ing, Media and Technology, 30(2), pp.185-199. https://doi.org/10.1080/17439880500093810

[12] Kirschner, P.A. and Karpinski, A.C., 2010. Facebook ${ }^{\circledR}$ and academic performance. Computers in human behavior, 26(6), pp.1237-1245. https://doi.org/10.1016/j.chb.2010.03.024

[13] Lei, J. and Zhao, Y., 2007. Technology uses and student achievement: A longitudinal study. Computers \& Education, 49(2), pp.284-296. https://doi.org/10.1016/j.compedu.2005. $\underline{06.013}$

[14] López-Pérez, M.V., Pérez-López, M.C. and Rodríguez-Ariza, L., 2011. Blended learning in higher education: Students' perceptions and their relation to outcomes. Computers \& education, 56(3), pp.818-826. https://doi.org/10.1016/j.compedu.2010.10.023

[15] Machin, S. and McNally, S., 2005. Gender and student achievement in English schools. Oxford review of economic policy, 21(3), pp.357-372. https://doi.org/10.1093/oxrep/gri021

[16] Markle, G., 2015. Factors influencing persistence among nontraditional university students. Adult Education Quarterly, 65(3), pp.267-285. https://doi.org/10.1177/0741713615583085

[17] Muduli, J.R., 2014. Addiction to technological gadgets and its impact on health and lifestyle: a study on college students (Doctoral dissertation).

[18] Nasar, J., Hecht, P. and Wener, R., 2008. Mobile telephones, distracted attention, and pedestrian safety. Accident analysis \& prevention, 40(1), pp.69-75. https://doi.org/10.1016/ j.aap.2007.04.005

[19] Robbins, S.B., Lauver, K., Le, H., Davis, D., Langley, R. and Carlstrom, A., 2004. Do psychosocial and study skill factors predict college outcomes? A meta-analysis. Psy-chological bulletin, 130(2), p.261. https://doi.org/10.1037/0033-2909.130.2.261

[20] Starcevic, V. 2012. Is Internet Addiction a Useful Concept?. Australian and New Zealand Journal of Psychiatry, Vol. 47(1), p 16-19. https://doi.org/10.1177/0004867412461693

[21] Stewart, S., Lim, D.H. and Kim, J., 2015. Factors Influencing College Persistence for FirstTime Students. Journal of Developmental Education, 38(3), pp.12.

[22] Wallace, P. 2014. Internet Addiction Disorder and Youth. Embo Reports, Vol 15(1), pp.1216. https://doi.org/10.1002/embr.201338222

[23] Weinstein, A., Feder, L.C., Rosenberg, K.P. and Dannon, P., 2014. Internet addiction disorder: Overview and controversies. In Behavioral addictions (pp. 99-117).

[24] World Statistics. Mobile cellular subscriptions (per 100 people). http://world-statis$\underline{\text { tics.org/indexres.php? code=IT.CEL.SETS.P2?name=Mobile } \% 20 \text { cellular } \% 20 \text { subscriptions }}$ \%20(per\%20100\%20people)\#top-result [Accesed 20 July 2018] 
[25] Yeboah, J. and Ewur, G.D., 2014. The impact of whatsapp messenger usage on stu-dents performance in Tertiary Institutions in Ghana. Journal of Education and prac-tice, 5(6), pp.157-164.

[26] Yuan, L., Powell, S. and CETIS, J., 2013. MOOCs and open education: Implications for higher education.

\section{Authors}

Ariana Yunita is a lecturer at Department of Computer Science, Universitas Pertamina, Jakarta, Indonesia. She received her master's degree from James Cook University, Australia. Her research interests are machine learning, data mining, and ICT for education. She has just started her doctoral study at Department of Computer Science, Universitas Indonesia.

Nursechafia is a lecturer at Department of Economics, Universitas Pertamina, Jakarta, Indonesia. During her tenure in the university, she has been awarded the best lecturer by Faculty of Economics and Business, Universitas Pertamina. Before starting as an academician, she worked as a research asistant at Central Bank of Indonesia (BI) and National Board of Zakat (BAZNAS). She has published widely in reputed international and national journals.

Erwin Setiawan is a lecturer of Computer Science Department in Universitas Pertamina. He received master's degree from Universitas Indonesia with specialities in IT Governance. Currently, he also has responsibility as Facility and ICT Director in Universitas Pertamina. He has more than 10 years of experience in ICT industry with various roles and responsibilities in IP Network, Network Operation Center Manager and Internet Operation Manager.

Herminarto Nugroho was born in Indonesia in 1988. He received B.Sc. in electrical engineering from President University, Indonesia (2010) and M.Sc. degrees in systems and control from Delft University of Technology (TU Delft), the Netherlands (2015). Since 2016, he is a Lecturer at Department of Electrical Engineering, Universitas Pertamina, Indonesia. His research interests are in smart control and machine learning.

Hani Ramadhan is a second-year PhD student in Big Data Department in Pusan National University. From 2016 to 2017, he served as a Computer Science lecturer in Universitas Pertamina, Indonesia. He received his master degrees from Informatics Engineering Department, Institut Teknologi Sepuluh Nopember, and Complex System and Interaction Department, Universite de Technologie de Compiegne, in a joint-degree scheme in 2015. His research interest covers data mining, deep learning, and computer vision.

Article submitted 12 September 2018. Resubmitted 23 October 2018. Final acceptance 23 October 2018. Final version published as submitted by the authors. 